\title{
ISI ATAU MUATAN SURAT KUASA DAN BATASAN WEWENANG PEMBERI \\ KUASA DI PENGADILAN TATA USAHA NEGARA
}

\author{
Sabam Sirait S \\ Email: sabamsiraits1@gmail.com \\ Bp: 2010003600026 \\ Universitas Ekasakti Padang
}

\section{A. PENDAHULUAN}

Pengertian surat kuasa secara umum, dapat dirujuk dari Pasal 1792 KUHPerdata, yang menyatakan: "pemberian kuasa adalah suatu persetujuan dengan mana seorang memberikan kekuasaan kepada seorang lain, yang menerimanyauntuk dan atas namanya menyelenggarakan suatu urusan". Bertitik tolak dari ketentuan Pasal tersebut, dalam perjanjian kuasa, terdapat dua pihak yang terdiri atas: pemberi kuasa dan penerima kuasa yang diberi perintah atau mandat melakukan sesuatu untuk dan atas nama pemberi kuasa.

Surat kuasa adalah surat yang digunakan untuk melimpahkan wewenang dari pihak yang secara sah memiliki wewenang kepada pihak lain. Pihak lain ini nantinya yang akan mewakili pihak pemilik wewenang dan mempunyai otoritas penuh terhadap objek pelimpahan kuasa seperti yang disebutkan dalam surat kuasa.

Surat kuasa adalah suatu dokumen di mana isinya seseorang menunjuk dan memberikan wewenang pada orang lain untuk melakukan perbuatan hukum untuk dan atas namanya. Menurut Pasal 1792 KUHPerdata, pemberian kuasa adalah suatu perjanjian dengan mana seorang memberikan kekuasaan kepada seorang lain, yang menerimanya untuk dan atas namanya menyelenggarakan suatu urusan.

Menurut KUHPerdata pemberian kuasa dibagi menjadi kuasa umum dan kuasa khusus.Kuasa yang diberikan secara umum menurut Pasal 1796 KUHPerdata adalah Pemberian kuasa yang dirumuskan secara umum hanya meliputi tindakan-tindakan yang menyangkut pengurusan untuk memindahtangankan barang atau meletakkan hipotek di atasnya, untuk membuat suatu perdamaian, ataupun melakukan tindakan lain yang hanya dapat dilakukan oleh seorang pemilik, diperlukan suatu pemberian kuasa 
dengan kata-kata yang tegas. Meliputi perbuatan-perbuatan pengurusan yang mencakup segala kepentingan pemberi kuasa, kecuali perbuatan yang hanya dapat dilakukan oleh seorang pemilik. Misalnya melakukan tindakan pengurusan, penghunian atau pemeliharaan seperti membayar rekening listrik, telepon dan rekening air atau tindakan lain yang merupakan tindakan pengurusan (beheer) sementara terhadap sebuah rumah atau lebih yang terletak di kota tertentu atau jalan tertentu.

Sedangkan yang dimaksud dengan surat kuasa khusus menurut Pasal 1795 KUHPerdata adalah hanya mengenai satu kepentingan tertentu atau lebih, atau secara umum, yaitu meliputi segala kepentingan pemberi kuasa.Hanya mengenai satu kepentingan tertentu atau lebih, oleh karena itu diperlukan suatu pemberian kuasa yang menyebutkan dengan tegas perbuatan meletakkan atau membebankan hak atas barang bergerak seperti hipotek atau hak tanggungan, yang hanya dapat dilakukan oleh seorang pemilik.Pemberian surat kuasa khusus sebagaimana yang dimaksud dalam KUHPerdata tersebut, salah satunya adalah pemberian Surat Kuasa Pembebanan Hak Tanggungan.

Di mana sejak diterbitkan Undang-Undang Nomor 4 Tahun 1996 tenntang Hak Tanggungan Atas Tanah Beserta Benda-Benda yang Berkaitan Dengan Tanah (UndangUndang Hak Tanggungan) tersebut, maka Surat Kuasa tersebut dikenal sebagai Surat Kuasa Membebankan Hak Tanggungan (SKMHT). Pembebanan hak tanggungan atas tanah,sebagaimana diketahui adalah dituangkan dalam suatu Akta Pemberian Hak Tanggungan (APHT) yang dibuat oleh Pejabat Pembuat Akta Tanah (PPAT), sebagai bukti tentang pemberian hak tanggungan yang berkedudukan sebagal dokumen perjanjian kedua yang melengkapi dokumen perjanjian utang sebagai perjanjian pokok. Dalam pembuatan APHT dilakukan oleh debitur atas objek jaminan kredit, yang dalam praktek dapat dilakukan oleh pihak bank (kreditur) atas dasar kuasa yang diberikan oleh debitur dengan Surat Kuasa Membebankan Hak Tanggungan (SKMHT). Menurut Pasal 1171 KUHPerdata mengatakan kuasa untuk memasang hak tanggungan hanya dapat diberikan dengan suatu akta otentik, kecuali dengan hal-hal yang dengan tegas ditunjuk oleh Undang-Undang. 


\section{B. PEMBAHASAN}

\section{Surat Kuasa}

Menurut Pasal 1792 KUH Perdata Pemberian Kuasa adalah suatu perjanjian dengan mana seorang memberikan kekuasaan (wewenang) kepada seorang lain, yang menerimanya untuk atas namanya menyelenggarakan suatu urusan. Apabila dilihat dari cara terjadinya, perjanjian pemberian kuasa dibedakan menjadi enam macam, yaitu: akta umum, surat di bawah tangan, lisan, diam-diam, cuma-cuma, kata khusus, dan umum (Pasal 1793 s.d. Pasal 1796 KUH Perdata).

Secara umum, surat kuasa tunduk pada prinsip yang diatur dalam bab keenam belas, buku III KUHP Perdata, sedanakan aturan khususnya diatur dan tunduk akan ketentuan hukum acara yang digariskan HIR dan RBG. Oleh karena itu, perlu disinggung secara ringkas beberapa prinsip hukum pemberian kuasa, yang dianggap berkaitan dengan kuasa khusus. Untuk memahami pengertian kuasa secara umum, dapat dirujuk pasal $1792 \mathrm{KUH}$ perdata, yang berbunyi: "pemberian kuasa adalah suatu persetujuan dengan mana seseorang memberikan kuasa kepada seorang lain, yang menerimanya, untuk dan atas nama penyelenggaraan suatu urusan". Bertitik tolak dari ketentuan pasal tersebut, dalam perjanjian kuasa, terdapat dua pihak yang terdiri dari:

- Pemberi kuasa atau lastgever (instruction, mmandatg)

- Penerima kuasa atau disingkat kuasa, yang diberi perintah atau mandat melakukan sesuatu untuk dan atas nama pemberi kuasa. Lembaga hukumnya disebut pemberian kuasa atau disebut latsgeving (volmacht, full power ), jika :

- Pemberi kuasa melimpahkan kuasa atau mewakilkan kepada penerima kuasa untuk mengurus kepentingannya, sesuai fungsi dan kewenangan yang ditentukan dalam surat kuasa.

-Dengan demikian penerima kuasa (latshebber, mandatory) berkuasa penuh, bertindak mewakili pemberi kuasa terhadap pihak ketiga dan unguk atas nama pemberi kuasa.

Oleh karena itu, pemberi tanggungbjawab atas segala perbuatan kuasa, sepanjang perbuatan yang dilakukan kuasa tidak memiliki wewenang yang diberikan pemberi kuasa.Pada dasarnya, pasal-pasal yang mengatur pemberian kuasa, tidak bersifat impreatif. Apabila para pihak menghendaki, dapat disepakati selain yang digariskan dalam undang-undang. Misalnya, para pihak dapat menyepakati agar pemberian kuasa tidak dapat dicabut kembali(irrevocable). Hal ini dimungkinkan, karena pada umumnya 
pasal-pasal hukum perjanjian, bersifat mengatur (aannvuled recht).

$>$ Isi Surat Kuasa

Isi surat kuasa terdiri atas:

a). Nama Pejabat, pangkat, NIP dan jabatan yang memberi kuasa.

b). Nama jabatan yang memberi kuasa.

c). Tulisan "memberi kuasa”.

d). Tulisan "kepada".

e). Nama pejabat yang diberi kuasa

f). Nama jabatan yang diberi kuasa.

g). Tulisan "untuk".

h). Hal-hal yang menyangkut jenis tugas dan tindakan yang dikuasakan.

\section{Surat Kuasa Membebankan Hak Tanggungan (SKMHT)}

Menurut Pasal 1 ayat 5 Undang-undang Nomor 4 Tahun 1996 Surat Kuasa Membebankan Hak Tanggungan (SKMHT) adalah suatu kuasa yang diberikan debitur (pemilik barang jaminan) untuk hadir di hadapan PPAT dalam pembuatan APHT dalam rangka pembebanan hak tanggungan kepada kreditur (pihak lain) yang berbentuk akta otentik.

\section{Sifat Perjanjian Kuasa}

a. penerima kuasa langsung berkapasitas sebagai wakil pemberi kuasa, Pemberian kuasa tidak hanya bersifat mengatur hubungan internal antara pemberi kuasa dan penerima kuasa. Akan tetapi, hubungan hukum itu langsung menerbitkan dan memberi kedudukan serta kapasitas kepada kuasa menjadi wakil penuh (full power) pemberi kuasa, yaitu:

- Memberi hak dan kewenangan (authority) kepada kuasa, bertindak untuk dan atas nama pemberikuasa terhadap pihak ketiga.

- Tindakan kuasa tersebut langsung mengikat kepada diri pemberi kuasa, sepanjang tindakan yang dilakukan kuasa tidak melampau batas kewenangan yang dilimpahkan pemberi kuasa kepadanya. 
- Dalam ikatan hubungan hukum yang dilakukan kuasa dengan pihak ketiga, pemberi kuasa berkedudukan sebagai pihak materiil atau principal atau pihak utama, dan penerima kuasa berkedudukan dan berkapasitas sebagai pihak formil.

Akibat hukum dari hubungan yang demikian, segala tindakan yang dilakukan kuasa kepada pihak ketiga dalam kedudukannya sebagai pihak formil, mengikat kepada pemberi kuasa sebagai principal (pihak materill).

b. Pemberi kuasa bersifat konsensual sifat perjanjian atau persetujuan kuasa adalah konsensual, yaitu perjanjian berdasarkan kesepakatan (agreement) dalam arti:

- Hubngan pemberi kuasa, bersifat partai yang terdiri dari pemberi dan penerima kuasa.

- Hubungan hukum itu dituangkan dalam perjanjian pemberian kuasa, berkekuatan menginkat sebagai pemberi persetujuan di antara mereka (kedua belah pihak).

- Oleh karena itu, pemberi kuasa harus dilakukan berdasarkan pernyataan kehendak yang tegas dari kedua belah pihak.

Itu sebabnya pasal 1792 dan pasal 1793 ayat $1 \mathrm{KUH}$ perdata menyatakan, pemberian kuasa selain didasarkan persetujuan kedua belah pihak, dapat dituangkan dalam bentuk akta otentik atau dibawah tangan maupun dengan lisan. Namun demikian, tanpa mengurangi penjelasan diatas, berdasarkan pasal 1793 ayat $2 \mathrm{KUH}$ Perdata, penerimaan kuasa dapat terjadi secara diam-diam, dan hal itu dapat disimpulkan dari pelaksaan kuasa itu oleh pemberi kuasa. Akan tetapi, cara diam-diam ini, tidak dapat diterapkan dalam pemberian kuasa khusus. Kuasa khusus harus disepakati secara tegas dan harus dituangkan dalam bentuk akta atau surat kuasa khusus.

c. Berkarakter garansi-kontrak Ukuran untuk menentukan kekuatan mengikat tindakan kuasa kepada principal (pemberi kuasa), hanya terbatas;

- Sepanjang kewenangan (volmacht) atau mandat yang diberikan oleh pemberi kuasa.

- Apabila kuasa melampaui batas mandat, tanggungjawab pemberi kuasa hanya sepanjang tindakan, yang sesuai mandat yang diberikan. Sedangkan pelampauan itu menjadi tanggung jawab kuasa, sesuai dengan asas "garansi-kontrak" yang digariskan pasal $1806 \mathrm{KUH}$ perdata.

Dengan demikian, hal-hal yang dapat diminta tanggung jawab pelaksanaan dan pemenuhannya kepada pemberi kuasa, hanya sepanjang tindakan yang sesuai dengan mandat atau intruksi yang diberikan. Di luar itu, menjadi tanggungjawab kuasa, sesuai 
anggapan hukum: atas tindakan kuasa yang melampaui batas, kuasa secara sadar telah memberi garansi bahwa dia sendiri yang akan memikul pelaksanaan pemenuhannya.

\section{Berakhirnya Kuasa}

Pasal 1813 KUH Perdata, membolehkan berakhirnya perjanjian kuasa secara sepihak atau unilateral. Ketentuan ini secara diametral bertentangan dengan pasal 1338 $\mathrm{KUH}$ Perdata ayat 2 yang menegaskan bahwa, persetujuan tidak dapat ditarik atau dibatalkan secara sepihak tetapi harus didasarkan kesepakatan kedua belah pihak (secara bilateral"). Hal-hal yang dapat mengakhiri pemberian kuasa menurut pasa 1813 KUH Perdata:

a. Pemberian kuasa menarik kembali secara sepihak Ketentuan penarikan atau pencabutan kembali kuasa oleh pemberi kuasa diatur lebih lanjut dalam pasal 1814 $\mathrm{KUH}$ perdata dan seterusnya, dengan acuhan:

- Pencabutan tanpa memerlukan persetujuan daripenerima kuasa. Pencabutan dapat dilakukan secara tegas dengan bentuk:

1. Mencabut secara tegas dengan tertulis atau,

2. Meminta kembali surat kuasa darimpenerima kuasa.

- Pencabutan secara diam-diam, berdasarkan pasal 1816 KUH prdata. Caranya, pemberi kuasa mengangkat atau menujuk kuasa baru untuk melaksanakan urusan yang sama. Tindakan itu berakibat, kuasa yang pertama, terhitung sejak tanggal pemberian kuasa kepada kuasa yang baru, ditarik secara diam-diam. Sehubung dengan pencabutan secara sepihak, ada baiknya dilakukan secara terbuka, dengan cara memberitahukannya atau dengan mengumumkannya. Cara yang demikian, memberi perlindungan hukum kepada pemberi kuasa maupun kepada pihak ketiga, karena sejak itu, setiap tindakan yang dilakuakan kuasa untuk dan atas nama pemberi kuasa, tidak sah dan dianggap melawan hukum, sehingga tidak dapat dipertanggungjawabkan kepada pemberi kuasa. Sebaliknya jika pencabutan tidak terbuka, semua tindakan hukum yang dilakukannya dengan pihak ketiga yang beritikad baik, tetap mengikat kepada pemberi kuasa. Sebaliknya jika pencabutan tidak terbuka, semua tindakan hukum yang dilakukannya dengan pihak ketiga yang beritikad baik, tetap mengikat kepada pemberi kuasa.

b. Salah satu pihak meninggal

Pasal $1813 \mathrm{KUH}$ perdata menegaskan, dengan meninggalnya salah satu pihak dengan sendirinya pemberi kuasa berakhir demi hukum. Hubungan hukum perjanjian 
kuasa, tidak berlanjut kepada ahli waris. Jika hubungan itu hendak dilanjutkan oleh ahli waris, harus dibuat surat kuasa baru. Paling tidak, ada penegasan tertulis dari ahli waris yang berisi pernyataan, melanjutkan persetujuan pemberin kuasa dimaksud.

c. Penerima kuasa melepas kuasa

Pasal 1817 KUH perdata, memberi hak secara sepihak kepada kuasa untuk melepaskan kuasa yang diterimanya, dengan syarat;

- Harus memberitahu kehendak pelepasan itu kepada pemberi kuasa;

- Pelepasan tidak boleh dilakukan pada saat yang tidak layak.

Ukuran tentang ini, didasarkan pada perkiraan objektif, apakah pelepasan itu dapat menimbulkan kerugian kepada pemberi kuasa.

\section{Dapat disepakati kuasa mutlak}

Untuk menghindari ketidak pastian pemberi kuasa, dihubungkan dengan hak pemberi kuasa untuk dapat mencabut secara sepihak pada satu sisi, serta hak penerima kuasa untuk melepas secara sepihak pada sisi lain, lalu intas pergaulan hukum telah memperkenalkan dan membenarkan pemberian kuasa mutlak.

Perjanjian kuasa seperti ini diberi nama "kuasa mutlak" yang memuat klausul:

-Pemberi kuasa tidak dapat mencabut kembali kuasa yang diberikan kepada penerima kuasa;

-Meninggalnya pemberi kuasa, tidak mengakhiri perjanjian pemberian kuasa.

Kedua bentuk klausul diatas, merupakan ciri terciptanya persetujuan kuasa mutlak. Klausul itu, menyingkirikan ketentuan pasa 1813 KUH Perdata, sehingga ada yang berpendapat, persetujuan kuasa mutlak bertentangan dengan hukum. Akan tetapi, pendapat itu dikesampingkan dalam praktik peradilan yang membenarkan persetujuan yang demikian. Diperbolekannya membuat persetujuan kuasa mutlak, bertitik tolak dari prinsip kebebasan berkontrak (freedom of contract) yang digariskan dalam pasal 1338 $\mathrm{KUH}$ perdata. Asas ini menegaskan, para pihak bebas mengatur kebebasan kesepakatan yang mereka kehendaki, sepanjang hal itu tidak bertentangan dengan pasal $1337 \mathrm{KUH}$ perdata, yaitu kesepakatan itu tidak mengandung hal yang dilarang (prohibition) oleh undang-undang atau berlawanan dengan kesusuliaan dan ketertiban umum (morals and public order).

Pendapat dan pendirian itu, dipedomani yurisprudensi Salah satu diantaranya, 
putusan MA No. $3604 \mathrm{k} / \mathrm{pdt} / 1985$. Putusan ini merupakan penegasan ulang atas pertimbangan hukum yang dikemukakan dalam putusan MA No. 731 k/sip/1975,5 yang antara lain menyatakan :

- Surat kuasa mutlak, tidak dijumpai aturannya dalam KUH perdata.

Namun demikian, yurisprudensi mengakui keberadaannya sebagai suatu syarat yang selalu diperjanjikan menurut kebiasaan, atau menurut kebiasaan selamanya diperjanjikan (bestendig gebruikelijk beding) atau disebut juga perpetual and usual or customary condition.

- Putusan MA No. 731 k/sip/1975 telah menegaskan ketentuan pasal 1813 KUH perdata, tidak bersifat limitatif dan juga tidak mengikat. Oleh karena itu, jika para pihak dalam perjanjian menghendaki, dapat disepakati agar pemberian kuasa tidak dapat dicabut kembali.

Pendirian ini, didasarkan pada doktrin bahwa pasal-pasal hukum perjanjian adalah hukum yang bersifat mengatur. Begitu juga meninggalnya pemberi kuasa dikaitkan dengan surat kuasa mutlak,telah diterima penerapannya diindonesia sebagai sesuatu yang telah bestendig, sehingga dianggap tidak bertentangan dengan pasal 1339 dan pasal $1347 \mathrm{KUH}$ perdata. Akan tetapi harus di ingat kembali larangan yang dimuat dalam intruksi Mendagri No. 14 tahun 1982.

Notaris dan PPAT dilarang memberi surat kuasa mutlak dalam transaksi jual beli tanah. Pemilik tanah dilarang memberi kuasa mutlak kepada kuasa untuk menjual tanah miliknya. Alasan larangan itu,dijelaskan dalam putusan MA No. 2584 k/pdt/1986 (14-41988), yang mengatakan; surat kuasa mutlak, mengenai jual beli tanah, tidak dapat dibenarkan dalam praktiknya sering disalahgunakan untuk menyeludupkan jual beli tanah. 


\section{PENUTUP}

Menurut Pasal 1792 Kitab Undang-Undang Hukum Perdata (KUH Perdata) Pemberian kuasa ialah suatu persetujuan yang berisikan pemberian kekuasaan kepada orang lain yang menerimanya untuk melaksanakan sesuatu atas nama orang yang memberikan kuasa. Dengan demikian surat kuasa adalah suatu alat yang kini mepermudakan seseorang untuk melakukan urusan dalam bidang hukum untuk mengurus kepentingannya lewat orang kedua yang membantu dengan ketentuanketentuan yang telah disepakati bersama.

Dari semua data yang telah saya dapat, saya menyimpulkan bahwa Surat Kuasa memiliki banyak sekali keguaan dalam kehidupan sehari-hari kita. Surat kuasa ini dapat saja dipakai di lembaga hukum dan lembaga lainnya. Surat kuasa menggunakan bahasa yang baku dan tepat. Surat kuasa juga harus memakai identitas diri penerima dan identitas diri pemberi.

Akibat hukum terhadap Surat Kuasa Membebankan Hak Tanggungan jika pemberi kuasa meninggal dunia dilihat menurut aturaan SKMHT yang dibuat oleh beberapa Notaris terdapat klausula yang menyatakan bahwa " Kuasa yang diberikan tidak dapat ditarik kembali dan tidak dapat berakhir karena sebab apapun juga kecuali oleh karena telah dilaksanakan pembuatan akta pemberian hak tanggungan serta pedaftarannya atau karena tanggal tersebut telah terlampaui tanpa dilksanakan pembuatan akta pemberian hak tanggungan". Dan dihubungkan dengan Pasal 1813 KUHPerdata tentang berakhirnya pemberian kuasa tentu menjadi tidak produktif, artinya terdapat suatu aturan yang bertentangan dengan norma hukum khususnya Pasal 1813 KUHPerdata. Dimana suatu norma hukum tidak boleh saling bertentangan satu sama lain, sehingga tidak memunculkan penafsiran yang berbeda-beda dan benturan hukum dalam memahami norma hukum tersebut. 


\section{DAFTAR PUSTAKA}

Darmini Roza dan Laurensius Arliman S, Peran Pemerintah Daerah Di Dalam Melindungi Hak Anak Di Indonesia, Masalah-Masalah Hukum, Volume 47, Nomor 1, 2018. https://doi.org/10.14710/mmh.47.1.2018.10-21

Laurensius Arliman S, Peranan Metodologi Penelitian Hukum di Dalam Perkembangan Ilmu Hukum di Indonesia, Soumatera Law Review, Volume 1, Nomor 1, 201. http://doi.org/10.22216/soumlaw.v1i1.3346.

Laurensius Arliman S, Peran Badan Permusyawaratan Desa di Dalam Pembangunan Desa dan Pengawasan Keuangan Desa, Padjadjaran Journal of Law, Volume 4,

Nomor 3, 2017. https://doi.org/10.15408/jch.v4i2.3433.

Laurensius Arliman S, Penanaman Modal Asing Di Sumatera Barat Berdasarkan UndangUndang Nomor 25 Tahun 2007 Tentang Penanaman Modal, Supremasi Hukum, Volume 1, Nomor 1, 2018. http://dx.doi.org/10.36441/hukum.v1i01.102.

Laurensius Arliman S, Memperkuat Kearifan Lokal Untuk Menangkal Intoleransi Umat Beragama Di Indonesia, Ensiklopedia of Journal, Volume 1, Nomor 1, 2018, https://doi.org/10.33559/eoj.v1i1.18.

Laurensius Arliman S, Perkawinan Antar Negara Di Indonesia Berdasarkan Hukum Perdata Internasional, Kertha Patrika, Volume 39, Nomor 3, 2017, https://doi.org/10.24843/KP.2017.v39.i03.p03.

Laurensius Arliman S, Partisipasi Masyarakat Di Dalam Pengelolaan Uang Desa Pasca UndangUndang Nomor 6 Tahun 2014 Tentang Desa, Jurnal Arena Hukum, Volume 12, Nomor 2, 2019, https://doi.org/10.21776/ub.arenahukum.2019.01202.5.

Laurensius Arliman S, Mewujudkan Penegakan Hukum Yang Baik Di Negara Hukum Indonesia, Dialogica Jurnalica, Volume 11, Nomor 1, 2019, https://doi.org/10.28932/di.v11i1.1831.

Laurensius Arliman S, Mediasi Melalui Pendekatan Mufakat Sebagai Lembaga Alternatif Penyelesaian Sengketa Untuk Mendukung Pembangunan Ekonomi Nasional, UIR Law Review, Volume 2, Nomor 2, 2018, (https://doi.org/10.25299/uirlrev.2018.vol2(02).1587

Laurensius Arliman S, Peranan Filsafat Hukum Dalam Perlindungan Hak Anak Yang Berkelanjutan Sebagai Bagian Dari Hak Asasi Manusia, Doctrinal, Volume 1, Nomor 2, 2016.

Laurensius Arliman S, Ni Putu Eka Dewi, Protection of Children and Women's Rights in Indonesia through International Regulation Ratification, Journal of Innovation, Creativity and Change Volume 15, Nomor 6, 2021. 
Laurensius Arliman S, Gagalnya Perlindungan Anak Sebagai Salah Satu Bagian Dari Hak Asasi Manusia Oleh Orang Tua Ditinjau Dari Mazhab Utilitarianisme, Jurnal Yuridis, Volume 3, Nomor 2, 2016, http://dx.doi.org/10.35586/.v3i2.180.

Laurensius Arliman S, Tantangan Pendidikan Kewarganegaraan Pada Revolusi 4.0, Jurnal Ensiklopedia Sosial Review, Volume 2, Nomor 3, 2020.. 